POLITICS AND INTERNATIONAL RELATIONS

\title{
Party Systems, Political Competition, and Inequality in Subnational Brazil
}

\author{
Vincent Mauro \\ Cornell University, US \\ vrm38@cornell.edu
}

\begin{abstract}
Many have attributed the recent unprecedented wave of redistribution in Brazil to national economic and political factors such as the commodities boom, changes in minimum wages or premiums to skilled labor, the rise of the Partido dos Trabalhadores and President Luiz Inácio Lula da Silva and a commodities-driven economic boom. Yet much less attention has been devoted to the study of inequality at the subnational level, where trajectories of inequality across states remain incredibly varied. This article argues that Brazil's most recent democratic transition enhanced political competition in many Brazilian states, which in turn has contributed to the amelioration of inequality. Using an original time-series cross-sectional dataset covering the highly redistributive period of 1998-2015, this article finds that Brazilian states with higher political and party competition have lower levels of inequality than those with less competitive party systems.
\end{abstract}

\begin{abstract}
Muitos atribuíram a onda recente de renda redistribuição no Brasil por fatores econômicos e politicais nacionais como o 'boom de commodities,' câmbios no salários-mínimos, prêmios mais baixos para mão de obra qualificada, e a ascensão do Partido dos Trabalhadores e o Presidente Luiz Inácio Lula da Silva. Embora, muito menos atenção foi dedicada para a pesquisa de desigualdade no nível subnacional, onde niveles relativos de desigualdade através os estados permanecem incrivelmente variados. Esse artigo faz o argumento que a transição democrática mais recente no Brasil aumentada competição em os sistemas de partidos de alguns estados, que por sua vez contribuiu para a melhoria de desigualdade. Utilizando dados do período 1998-2015, assim como análise qualitativa um par de estados, Pará e Rio Grande do Sul, esse artigo encontra os estados brasileiros com sistemas partidos mais competitivo são mais prováveis para avançar politicais de sociais e ter niveles mais baixos de desigualdade que outros com sistemas partidos menos competitivos.
\end{abstract}

Despite remaining one of the world's most unequal countries, Brazil has experienced an unprecedented wave of income redistribution in the twenty-first century. Substantial drops in income inequality prompted literature focusing on national level dynamics such as the commodities boom, changes in minimum wages or premiums to skilled labor, the rise of the Partido dos Trabalhadores (PT) and President Inácio Lula da Silva, and heralded social programs such as Bolsa Família. Much less attention, however, has been devoted to studying inequality at the subnational level despite substantial variation in levels of inequality across Brazilian states. Although there is a general trend of decreasing inequality across a majority of Brazilian states, some states continue to rank among the most unequal in the world, while others exhibit levels of inequality that are roughly comparable to countries of southern Europe. Despite exposure to comparable macro-level redistributive, economic, and political conditions, why do states in contemporary Brazil exhibit such differing levels of inequality?

This article argues that struggles for redemocratization spurred the formation of a new cohort of more organized political parties, and their entrance into new political territories triggered asymmetrical ruptures of traditional politics and subsequent party system competition, affecting trajectories of redistributive social policy and levels of inequality across Brazilian states. Where robust party system competition has taken 
root, incentives for the advance of redistributive social policy and construction of pluralistic institutions have strengthened, placing downward pressure on inequality. In contrast, where traditional politics and uncompetitive party systems remain the status quo, programmatic social policy has been rare and state capture common, leading to the persistence of inequality.

Employing a time-series cross-sectional dataset covering twenty-seven Brazilian states over the period of 1998-2015, ${ }^{1}$ I find that Brazilian states with more robust party system competition are likelier to possess lower levels of economic inequality. I also make a qualitative paired comparison between the states of Pará and Rio Grande, showing that even in nearly polar opposite socioeconomic and political contexts, highly competitive party systems can directly contribute to the construction of more effective and inclusive political institutions, as well as the formulation and implementation of equity-enhancing social programs.

A growing literature stresses the importance of political competition in shaping redistributive and policy outcomes (Hecock 2006; Kitschelt and Wilkinson 2007; Díaz-Cayeros 2008; Pribble 2013; Ewig 2016; Fairfield and Garay 2017; González 2017). Rich, often qualitative work has theorized and empirically shown that differing environments of political and party system competition have contributed to divergent policymaking behavior across subnational Brazil (Borges 2008; Soares and Neiva 2011; Arvate 2013; Alves 2015; Niedzwiecki 2016, 2018). However, we lack a deep understanding for how these dynamics of competition shape socioeconomic outcomes across Brazilian states. This article contributes to the literature by continuing to develop and test causal mechanisms of subnational political competition and social policy making, and placing these theories into the domain of economic inequality.

\section{Subnational Inequality in Brazil}

Since the late 1990s Brazil has experienced an unprecedented amelioration of income inequality at the national level, dropping approximately 13 percent from 1998 to 2015. ${ }^{2}$ While many Brazilian states follow the national trends, there remains substantial variation in the levels of inequality across Brazilian states both at the genesis and in the wake of Brazil's historic redistributive wave. This variation in levels of inequality is evident in Figure 1, which visually represents inequality in all twenty-seven Brazilian states in two separate years, 2001 and $2015 .^{3}$

We should not expect uniform levels of inequality across the entirety of Brazil. Brazil is an extremely diverse country, both politically and economically, with historically stubborn regional patterns of socioeconomic development. The south and southeast have long histories of higher economic development, better

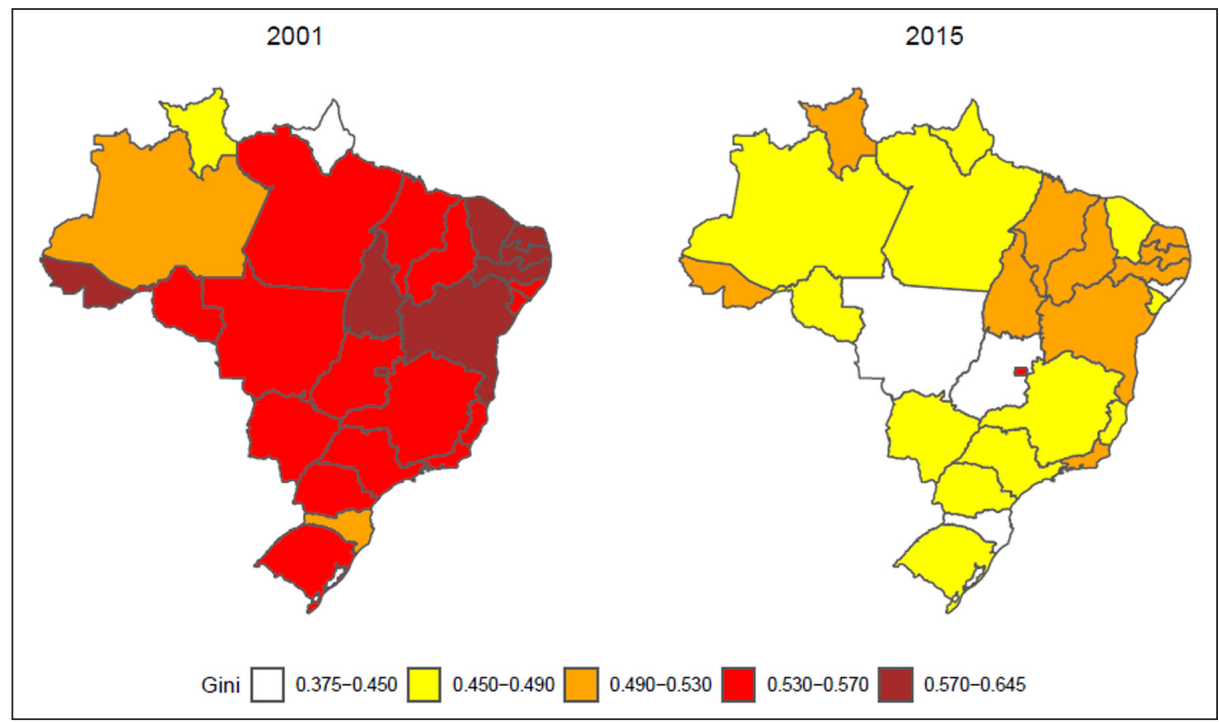

Figure 1: Subnational inequality in Brazil, 2001-2015.

\footnotetext{
${ }^{1}$ Although Brazil technically has twenty-six states and one federal district, this article treats Distrito Federal as a state for simplicity.

2 Gini (post-tax, post-transfer) dropped from 0.62 in 1998 to 0.54 in 2015 (Standardized World Income Inequality Database). Based on data attained in 2019 from https://fsolt.org/swiid/.

${ }^{3}$ Gini indices are calculated by the author using data from Pesquisa Nacional por Amostra de Domicílios Contínua (PNAD), microdata available here: https://www.ibge.gov.br/estatisticas/sociais/populacao/9171-pesquisa-nacional-por-amostra-dedomicilios-continua-mensal.html?=\&t=downloads. The individual trends of inequality for each state are provided in the appendix.
} 
socioeconomic conditions, and lower inequalities. Conversely, the northeast is particularly renowned for its comparative underdevelopment and staggering levels of social and economic inequality. Indeed, these comparative levels of development and economic growth within and across regions in Brazil have contributed to patterns of socioeconomic outcomes and inequality across Brazilian states (Bessaria et al. 2018). Yet it is also clear that socioeconomic differences across Brazilian regions do not explain the variation in inequality within regions. In the early 2000s, there was as much variation in relative levels of inequality across states in the northern region as across all Brazilian states. Presently the central and northeastern regions exhibit the most variation of inequality between states. Furthermore, intraregional patterns of inequality also do not account for why three states-Distrito Federal, Rio de Janeiro, and Santa Catarina-have such different levels of inequality than the other states within their respective regions. This variation should be puzzling considering their relatively comparable exposure to broader national political and economic conditions. Why are some Brazilian states so much more unequal than others, both in the past and present?

\section{Competitive Ruptures, Party System Competition, and Inequality}

The establishment of democracy at the national level does not necessarily result in the practice of democratic politics within all its constitutive subunits (Gibson 2013; Giraudy 2015; Gervasoni 2018). A common laggard in this respect is the development of strong and competitive party systems, where political practices or politicians tied to the authoritarian ancien régime often continue to persist at the local levels (Key 1949; Gibson and Suarez-Cao 2010). Brazil is no exception; traditional politics deeply rooted in patronage and clientelism have continued to survive in subnational Brazil (Hagopian 1996; Alves and Hunter 2017). Yet, while democratization does not guarantee the diffusion of robust democratic politics, it can provide an opportunity structure for the development of the organizational foundations necessary for subsequent formation of institutionalized political parties (Lipset and Rokkan 1967; Levitsky, Loxton, and Van Dyck 2016). Indeed, the struggle for democracy galvanized civil societal organizations that would serve as the organizational basis of the PT, the impetus for the Partido da Social Democracia Brasileira (PSDB) to break from the artificially manufactured opposition under the authoritarian regime, and the reestablishment of the previously barred Partido Socialista Brasileiro (PSB). Furthermore, the struggle for redemocratization contributed to the formation and growth of a new cohort of comparatively more organized political parties that would fundamentally alter the national, and subnational, political landscape.

The emergence and entrance of organized competitors into established and traditional political landscapes party systems caused competitive ruptures, disrupting the status quo and enhancing competition. Parties with roots from the redemocratization process-particularly, but not necessarily exclusively the PSB, PSDB, and PT-expanded on their localized influence by organizationally penetrating political territories outside their bases of predominantly São Paulo and the southeast, fundamentally altering existing party competition in their wake. ${ }^{4}$

Although a number of states' political landscapes have been fundamentally altered with the entrance of newly organized parties, these developments were not uniform across subnational Brazil. In some states, penetration by emerging parties was relatively unresisted, and traditional political networks fell in quick succession (Borges 2007; Montero 2012; Van Dyck and Montero 2015). In others, traditional politicians and parties entrenched themselves by employing significant resources to maintain or strengthen patronage and clientelistic linkages with voters, hindering the entrance of emerging parties or outright preventing them from deepening political competition within the state political system (Alves and Hunter 2017). I argue that this uneven party system competition across Brazilian states has contributed to divergent broader patterns of redistributive social policy and socioeconomic outcomes.

\section{Political competition, social policy making, and inequality}

Given that the highly federalized system in Brazil affords individual states with substantial leverage to design and implement their own social policy (Abrucio 1998; Borges 2008; Alves 2015; Niedzwiecki 2018), we should expect state politics to be relevant for affecting subnational socioeconomic outcomes. The 1988 Brazilian Constitution delegates significant powers to states to formulate and implement their own policy and to use some degree of their own discretion to manage expenditures and distribute resources to policy

\footnotetext{
${ }^{4}$ I avoid drawing a sharp analytical distinction between left and conservative parties often made in the literature (e.g., Montero 2012, 2014). Emerging parties were not exclusive to the left nor is traditional politics exclusive to conservatives. While the PSB, PSDB, and PT do exhibit greater organization and mass party behavior than many other parties, it should be noted that they actively harbor politicians that practice patronage and clientelistic strategies.
} 
realms such as education, health, housing, and social welfare and assistance. ${ }^{5}$ States also have the ability to collect their own taxes and revenue, typically from three sources: their own tax revenues, constitutional federal transfers, and discretionary federal transfers. ${ }^{6}$ Although the federal government reserves the power to tax incomes, state governments generate substantial revenues from indirect taxes such as the Tax on the Circulation of Goods and Services (ICMS) and the Tax on the Ownership of Automotive Vehicles (IPVA), which depending on the state can garner anywhere from 10 to 80 percent of their total budget.

Although much attention has centered on governors given their historically strong powers, party systems are integral actors for affecting social policy making and socioeconomic outcomes in subnational Brazil. First, competition within party systems affects electoral dynamics and outcomes. Political candidates vying for state legislative and gubernatorial positions heavily rely on coalitions comprised of multiple parties. In turn, party system competition exerts influence on not only whether certain candidates win elections but also which issues they campaign on. Second, party systems shape the formulation of legislation at both the legislative and executive levels. State legislatures react to the electoral arena, wield power to initiate legislation, and play an active role in policy formulation and implementation (Desposato 2001; Santos 2001). Governors are partially beholden to their coalitions and regularly grant cabinet and appointed positions to coalition partners; governors not capable of maintaining their legislative coalitions have been obstructed in the budgetary and policy-making process (Schneider 2006). As party system competition increases governors are less autonomous in their ability to pursue their own policy agendas (Schneider 2001). Therefore, while dynamics of competition within party systems are not exclusive to the domain of the legislative branch, they do contribute to shaping broader patterns of policy making at multiple levels of government.

More specifically, I argue that competitive party systems affect redistributive social policy in at least two ways: first, to encourage politicians across the ideological spectrum to advance more expansive and programmatic social policies to capture greater vote shares in closely contested elections, and second, to increase incumbent turnover and incentivize more inclusive institution-building, diminishing state capture and enhancing the effective implementation of social policy.

Highly competitive party systems incentivize individual parties and politicians-across the ideological spectrum-to pursue anticipated rewards from voters by incorporating programmatic and redistributive policies into their electoral platforms and legislative agendas to win close elections. Anticipated rewards are the electoral fruits that politicians and their parties receive after creating policies or programs that successfully alleviate socioeconomic problems. In the presence of robust competition, politicians and parties use social policies as a wedge to attract voters (Pribble 2013; Ewig 2016; Garay 2016), and in highly unequal countries like Brazil, politicians who formulate initiatives that successfully address socioeconomic issues are often handsomely rewarded at the ballot box (Hunter and Power 2007; Zucco 2013). Outside of anticipated rewards, competition also makes the formulation of more expansive and programmatic social policies more likely. As competition increases and the difference between winning and losing elections narrows, parties are incentivized to appeal to broader subsets of the voting population through programmatic and expansive policies to obtain marginal or unattached voters to secure victories in close elections (Díaz-Cayeros 2008). In contrast, environments with less or no political competition provide less incentive for centrist and conservative parties to pursue redistributive policies. More importantly, in uncompetitive party systems where one party, or set of parties, are dominant, political actors are able to merely maintain their political coalitions and supporters through patronage or clientelism (Kitschelt and Wilkinson 2007) or largely ignore swathes of the electorate because of a lack of a credible electoral threat.

Political competition within party systems can also shape institution building and the implementation of social programs. In party systems with a broader set of viable political contenders, incumbents have the incentive to form pluralistic institutions and social programs with clear sets of rules to protect future avenues of access and prevent their potential capture by political opponents (Borges 2008; Alves 2015). Not only do these more pluralistic arrangements increase the likelihood of incumbent turnover and enhance the effectiveness of policy implementation, but they have also been shown to lead to more improved socioeconomic outcomes because of their heightened access from the lower and middle classes (Touchton and Wampler 2014). In contrast, when political competition is low, incumbents from dominant coalitions are

\footnotetext{
${ }^{5}$ Although some limits, such as the Fourteenth Constitutional Amendment of 1996 and Twenty-Ninth Constitutional Amendment of 2000, do establish certain earmarking of revenues to education and health, the discretion Brazilian states have over their expenditures remains high.

${ }^{6}$ The main difference between constitutional and discretionary transfers is that the latter are not specifically mandated for any particular purpose.
} 
incentivized to construct institutions with some degree of centralized power from above, further cementing their continued access and power in the future (Alves 2015). Dominant parties and politicians situated in uncompetitive party systems are more likely to keep political institutions weak, often using state and bureaucratic resources and positions in exchange for political support and undermining the capacity of the state bureaucracy and implementation of social policy over the long term.

Although inequality is a complex phenomenon potentially influenced by an array of economic and social factors, we should expect that, ceteris paribus, reiterative processes of social policy implementation through more inclusive and effective institutions exert downward pressure on income inequality. In general, the theory advanced here expects that states with more competitive party systems are more likely to possess lower levels of inequality, while inequality is more likely to persist in states with less competitive party systems.

\section{Alternative Explanations}

Differences in social policy making and inequality in subnational Brazil may also be explained by other theories in the existing literature. Rather than competition within party systems, vertical competitioncompetition between the state and federal levels of government-may also shape policy making; whether state and federal governments are aligned politically has been shown to affect the distribution of discretionary funds as well as federal policy implementation in Brazil (Borges 2011; Soares and Neiva 2011; Brollo and Nannicini 2012; Niedzwiecki 2016, 2018). These theories would expect that nonaligned state governments would be more likely to advance redistributive social policies to claim credit for their possible successes, reducing levels of inequality.

Sources drawing from power resources theory (e.g., Huber and Stephens 2012) also consider partisanship to contribute to the advance of social programs and amelioration of inequality at the subnational level. Others associate stronger unionization and left party strength with lower levels of economic inequality across subnational units in countries such as Canada and the United States (e.g., Kellerman 2007; Kelly and Witko 2012). Some show political parties of the left to be associated with higher levels of social spending at the subnational level (Hecock 2006; González 2017; Gouvêa and Girardi 2019). In federal states where governors exhibit power to shape electoral politics, policy, and state budgets-as in Brazil (Abrucio 1998; Samuels and Abrucio 2000)-the partisanship of the governor may also affect the policy-making process and redistribution (Samuels 2003; González and Mamone 2015). Specific to the case of Brazil, the PT has also been theorized to have a direct redistributive effect on socioeconomic outcomes at the state and local levels. Previous literature shows strong relationships between PT governments and more robust participatory governance and public programs (Abers 2000; Baiocchi 2005), as well as better socioeconomic outcomes such as health indicators and life expectancy (Touchton and Wampler 2014). In sum, despite differences among the causal mechanisms, these theories would expect Brazilian states with stronger organization of left-wing parties to exhibit lower inequality and pursue more redistributive social policies than those predominantly controlled by centrist or conservative parties.

Beyond theories of competition, more sociological factors may also affect inequality. A burgeoning literature argues that civil society-particularly its relative strength and density-is integral for the advancement of social policy, provision of public services, and better socioeconomic outcomes (Wampler 2010; Donaghy 2011; Kale and Mazaheri 2019). In the case of Brazil, municipalities and regions with strong participatory government structures and robust civil societal organizations are more likely to exhibit higher economic performance and health indicators (Touchton and Wampler 2014; Touchton, Sugiyama, and Wampler 2017). Extant literature has also theorized that race or ethnicity may affect redistribution, either by dampening redistributive demands among the underprivileged due to poor social service provision (Morgan and Kelly 2017), or because of a lack of incorporation or complete exclusion of political demands from minority groups in the political and party system (Van Cott 2000). In countries with large segments of the population occupied by ethnic or racial minorities, welfare states may be truncated, less defined, and less effective (Pribble 2010), or redistributive outcomes may significantly differ by ethnicity or race (Lustig 2017).

\section{Research Design}

To mitigate inherent shortcomings of both quantitative and qualitative methods and offer a more comprehensive test of the theoretical claims, I employ a mixed-methods approach. A primary goal of the article is to empirically test theories of political and party system competition in the domain of socioeconomic outcomes. Given the complexity of inequality, quantitative analysis is especially attractive for its ability to systematically test the broader relationship and control for competing explanations. Yet 
statistical analysis possesses inherent constraints for illuminating how the theorized causal mechanisms initiate and drive changes in the outcome. A more balanced empirical strategy would also incorporate qualitative approaches-ideally employing the careful selection and analysis of case studies-to further test the theory and show more concretely how party system competition affects social policy and institution building in Brazilian states. With those objectives, I first test the relationship between party systems and inequality quantitatively then draw on a qualitative paired comparison to augment the empirical evidence in support of the theory.

\section{Measurement of inequality}

In contrast to cross-national inequality data that rely on inequality measures calculated from sources that employ varied microdata sampling techniques, scaling down to the subnational level presents an opportunity to draw on continuous sources of household data. Brazil is especially rich in this regard given the presence of an annual national household survey, the Pesquisa Nacional por Amostra de Domicílios (PNAD), which is relatively unique in its unusually large and geographically representative sample size of two hundred thousand Brazilian households. To measure subnational inequality, I construct state-level income Gini indices from PNAD microdata. In line with Calvo and Moscovich (2017), I calculate overall Gini indices using individual incomes for each Brazilian state, covering the period 2001-2015. ${ }^{7}$ Individual income levels include government transfers such as pensions and welfare assistance, and therefore the Gini coefficients employed here are post-transfer (net inequality).

Despite numerous well-documented limitations, Gini coefficients, and measures of dispersion in general, remain the most commonly used metric for analyzing income inequality because of their enhanced comparability across units and time. Gini indices are especially attractive here, in contrast to ratio measures, because they account for changes in income across all subsets of the population; indeed, the time period here experienced substantial changes in income levels across a wide array of income groups. Despite limitations, the Gini indices constructed here rely on continuous sources of microdata and draw on large sample sizes, therefore their reliability and comparability should be considered high.

\section{Measurement of explanatory variables}

Given that I stress party system competition as the crucial determinant of social policy making and socioeconomic outcomes, the independent variable should capture the degree of contestation between political parties in any given party system. A commonly used measure of political competition is margin of victory (e.g., Abramowitz 1991; Holbrook and Van Dunk 1993; Cleary 2007; Eifert, Miguel, and Posner 2010). Margin of victory-the difference in vote share between the first- and second-place parties-in any given election is pertinent here because of its comparability across units and time, and more importantly its directness in measuring how closely contested elections are between parties. In other words, margin of victory directly captures how competitive any given election is between multiple parties while excluding other potential extraneous factors, providing a straightforward and valid measure to capture the causal mechanisms of the theory.

Although margin of victory applies to virtually any election, legislative margin of victory in Assembleia Legislativa elections is the most valid measure for subnational party system competition in Brazil. First, given the theoretical focus on party systems, Assembleia Legislativa elections are the appropriate venue to measure party system competition because they include most, if not all, political parties in the Brazilian party system. In contrast, gubernatorial elections typically only include a fraction of the party system, reducing any potential measure of competition down to a mere slice of the universe of parties within the system. Furthermore, not only do Assembleia Legislativa exhibit nearly the entirety of the party system but they are also significantly more stable than gubernatorial elections in Brazil. Brazilian gubernatorial elections are some of the most volatile in the democratic world. ${ }^{8}$ Extremely high volatility scores signify that, effectively speaking, party systems are tenuous or nonexistent for a large proportion of Brazilian states; the parties vying for governor are likely to be completely different from one election to the next, causing any measure of party system competition utilizing gubernatorial elections to be rife with low levels of validity and reliability.

\footnotetext{
${ }^{7}$ Given that the PNAD is proportionally sampled by municipality and the large number of households sampled, there is little question that state-level samples are more than sufficient for constructing valid Gini coefficients from.

${ }^{8}$ See Appendix Table 4 for electoral volatility averages, where approximately half of Brazilian states possess scores of 50 or above, with a number over 80 .
} 
The measure of party system competition employed here possesses face validity and is congruent with thicker and qualitative descriptions of Brazilian subnational party systems in the literature (e.g., Borges 2007; Montero 2012). States in the north and northeast, often described as comparatively uncompetitive and clientelistic (Van Dyck and Montero 2015; Alves and Hunter 2017), exhibit the highest margins of victory. In contrast, southern and southeastern states-regions characterized as more competitive-possess the smallest margins of victory. On a more granular level, margins of victory are lowest in states often classified as especially competitive-such as Espírito Santo, Rio Grande do Sul, Roraima, and Santa Catarinaand highest in oligarchic states such as Alagoas, Ceará, and Goías (e.g., Borges 2007; Niedzwiecki 2018). One may contend that Brazil's highly fragmented multiparty system may render a margin of victory measure less precise. To mitigate these concerns, I employ an alternative measure of party system competition-simply the vote share of the first-place or winning party-that does not rely on margins between two particular parties, in robustness checks provided in the appendix.

To measure political alignment, I employ a trichotomous variable from Niedzwiecki (2018) that measures the degree of alignment in federal and subnational party coalitions. ${ }^{9}$ To measure partisanship in both the legislative and executive branches, I calculate the percentage of seats held by the left (hereafter referred to as the strength of left) as well as a dummy variable for ideological position of the governor's party. Following Huber and Stephens (2012), I code all Brazilian parties along an ideological scale, then calculate the percentage of seats in the Assembleia Legislativa held by individuals in left and center-left parties for each calendar year. ${ }^{10}$ To account for the partisanship of the executive branch, I construct an annual dummy variable for whether the governor is from a party of the left or center-left. ${ }^{11}$

To account for the potential effects of the PT, I construct a variable measuring the organizational density of the PT at the state level. Because the theory advanced here suggests that the PT partially contributed to enhancing political competition across subnational Brazil, any measurement of PT organization requires some caution. To minimize risks of endogeneity and prevent the explanatory variable of interest-political competition-from simply being a proxy for relative PT organization within states, the analyses require an exogenous control variable for PT organization. I construct PT organization from an entirely different source of data; as a percentage of all Processo de Eleições Diretas (PEDs) national votes for each state, interpolated between election years. ${ }^{12}$

This article assumes that political competition and partisanship are related but distinct phenomena. While the PT is a stalwart of the Brazilian left, it is far from the only left-wing party in the country. We should not assume that a corresponding rise in PT organization, or the strength of the left in general, or aggregate political competition are associated with one another. Indeed, none of the independent variables are highly correlated with one another. ${ }^{13}$

\section{Measurement of control variables}

Because previous research has found a relationship between civil society, social reform, and social service provision, it is necessary to control for the strength of civil society across space and time. To capture civil societal strength, this article follows Donaghy (2011) and Samuels and Zucco (2014) and constructs a control variable for civil society density. ${ }^{14}$ To account for racial differences, I also control for the percentage of nonwhite population. ${ }^{15}$

Because Brazilian states differ in their relative rates of expenditure on social spending and state capacity, it is also necessary to control for these differences across units. To account for relative levels of social spending, I calculate expenditure on social programs as a percentage of total state government expenditures. ${ }^{16}$ To account for differences in the capacity of state bureaucracies and control for relative levels of revenues

\footnotetext{
${ }^{9}$ The variable has a baseline category of alignment between governor and president's parties (0), and (1) if there are common parties in each respective coalition, or (2) if there are no parties in the coalitions of the governor or president (Niedzwiecki 2016, 471).

${ }^{10}$ I draw heavily on coding practices from Huber and Stephens (2012).

${ }^{11}$ The ideological position of the governor's party is coded identically as the strength-of-left measure.

${ }_{12}$ PEDs are internal elections within the PT held throughout the country every four years and have been used as a proxy to determine the strength of local PT organization (Van Dyck and Montero 2015). Data drawn from Ribeiro (2010) and official PT party documents.

${ }_{13}$ Pearson's $r$ correlations between all main explanatory variables employed here are below $+/-0.4$

${ }^{14}$ The measure is calculated from censuses conducted by the Instituto Brasileño de Geografía y Estadística (IBGE) of registered nonprofit organizations, following coding practices used in Samuels and Zucco (2014). The measure is the log of the absolute number of civil society organizations, divided by total state population.

${ }^{15}$ The measure is the addition of the self-identification categories of preta, amerela, parda, and indigena in the Brazilian census (IBGE). All data from IBGE is available here: https://www.ibge.gov.br/estatisticas/downloads-estatisticas.html.

${ }^{16}$ This variable was calculated by the addition of all state government expenditure on healthcare, education, social assistance, and pensions, divided by total state government expenditure. Data sourced from the Secretaria do Tesouro Nacional (STN). Data is available here: https://www.gov.br/tesouronacional/pt-br/estatisticas-fiscais-e-planejamento/estatisticas-fiscais-do-governo-geral.
} 
across states, I also control for tax extraction capacity. ${ }^{17}$ Despite disagreement on how to adequately operationalize and measure state capacity, rates of local-level tax extraction can provide an effective means for differentiating the power and extractive capacity of subnational political units (Harbers 2015). In the case of Brazil, where states have substantial leverage to collect their own tax revenues and rely on transfer funds from the federal government, states in which tax revenue is comparatively higher than the funds they receive from the federal government indicate higher extractive state capacity than those that predominantly rely on the federal government for revenues.

Inequality may also be driven by economic and social determinants other than political factors. To account for levels of economic development, GDP per capita is included in the analysis. ${ }^{18}$ However, GDP per capita does not necessarily account for differences in the types of economies across states, nor their relative dependence on commodity production and export. Brazil is a major commodities producer, and the commodities-driven economic boom from roughly 2000 to 2014 affected wages disproportionately across subnational Brazil (Costa, Garred, and Pessoa 2016). To account for state commodity production, I also control for the level of temporary crop production. ${ }^{19}$ We should also expect higher levels of education to blunt inequalities, and indeed, increases in education across populations has been shown to reduce premiums to labor and suppress levels of inequality in Brazil (Barros et al. 2010). To account for differences across states in levels of educational attainment, a proxy for primary completion-measured as the percentage of eligible population enrolled in secondary school-is included in the analysis. ${ }^{20}$

\section{Model specification}

To test the relationship between party system competition and inequality, I employ two-way fixed effects ordinary least squares models. In the absence of serial correlation and where the number of cross-sectional units (states) outstrips the number of years in the analysis, fixed effects OLS models are the most efficient model of choice (Wooldridge 2010, 321-325). Although scaling down to the subnational level does offer methodological benefits to eliminating certain confounding variables, it potentially introduces unobserved heterogeneity because of the rather arbitrary nature of subnational boundaries between states where broader national and unknown factors may be correlated with the explanatory, control, and dependent variables. Furthermore, temporal effects are also a concern with time-series cross-sectional data. Much of the analysis here overlaps a commodities boom, which brought economic shocks and wage inequalities to many areas of Brazil, especially those highly dependent on resource extraction (Costa, Garred, and Pessoa 2016). To mitigate these concerns, I take a conservative approach and include both unit and time fixed effects to reduce risks of unobserved heterogeneity across states and years.

\section{Quantitative Analysis Results}

Models 1, 2, and 3 in Table 1 regress inequality on the three main explanatory variables in isolation, while Model 4 includes all the independent political variables in the same model. Model 5 includes the full set of political and control variables. The results provide strong empirical support for the theory advanced here. Across all models, legislative margin of victory has a positive and statistically significant relationship with inequality: states with higher margins of victory are associated with higher levels of inequality. In other words, Brazilian states with more competitive party systems are much likelier to exhibit lower levels of inequality than those with less competitive counterparts.

The results show little support for other theories of competition or partisanship. Although political alignment shows a negative and statistically significant relationship in Model 4, it is not statistically significant in the bivariate relationship in Model 2 . The strength of left is not statistically significant in any of the models and, contrary to what these theories would predict, is positively associated with inequality. In contrast, although the relationship with executive ideology is in the expected direction, it is not statistically significant. These findings suggest party ideology is not a driving factor in shaping socioeconomic outcomes in subnational Brazil.

The only two control variables showing a robust and statistically significant relationship with inequality are social spending and nonwhite population. Social spending has a negative relationship with inequality. Unsurprisingly, in states where expenditure on social programs form a larger portion of the state budget,

\footnotetext{
${ }^{17}$ I measure tax extraction capacity by calculating the ratio between state revenues from taxes and federal transfers, calculated using data from the STN.

${ }_{18}$ GDP per capita data is sourced from the IBGE. The measure employed in the models is the log of GDP per capita.

${ }_{19}$ The measure is the annual value, in billions of reais, produced in temporary crops. Data derived from IBGE.

${ }^{20}$ The specific measure is the percentage of eligible individuals aged fifteen to seventeen enrolled in secondary school. Data drawn from IBGE.
} 
Table 1: Political determinants of inequality in subnational Brazil, 1998-2015.

\begin{tabular}{|c|c|c|c|c|c|}
\hline & 1 & 2 & 3 & 4 & 5 \\
\hline $\begin{array}{l}\text { Margin of victory } \\
\text { (legislative) }\end{array}$ & $\begin{array}{l}5.023^{*} \\
(2.297)\end{array}$ & & & $\begin{array}{r}4.627^{*} \\
(2.362)\end{array}$ & $\begin{array}{l}6.398^{*} \\
(2.831)\end{array}$ \\
\hline Political alignment & & $\begin{array}{l}-0.351 \\
(0.193)\end{array}$ & & $\begin{array}{r}-0.453^{*} \\
(0.219)\end{array}$ & $\begin{array}{l}-0.345 \\
(0.264)\end{array}$ \\
\hline Strength of left & & & $\begin{array}{r}1.250 \\
(1.513)\end{array}$ & $\begin{array}{r}1.075 \\
(1.643)\end{array}$ & $\begin{array}{l}-0.226 \\
(2.106)\end{array}$ \\
\hline Left governor & & & & $\begin{array}{l}-0.561 \\
(0.297)\end{array}$ & $\begin{array}{l}-0.696 \\
(0.386)\end{array}$ \\
\hline PT organization & & & & $\begin{array}{r}1.014 \\
(1.251)\end{array}$ & $\begin{array}{r}2.104 \\
(1,768)\end{array}$ \\
\hline GDP per capita (l0g) & & & & & $\begin{array}{l}-7.203 \\
(4.469)\end{array}$ \\
\hline Commodity production & & & & & $\begin{array}{r}0.006 \\
(0.042)\end{array}$ \\
\hline Education & & & & & $\begin{array}{l}-0.054 \\
(0.041)\end{array}$ \\
\hline Nonwhite population & & & & & $\begin{array}{r}-0.217^{*} \\
(0.065)\end{array}$ \\
\hline Civil society density (log) & & & & & $\begin{array}{r}3.169 \\
(2.759)\end{array}$ \\
\hline Social spending & & & & & $\begin{aligned}-8.539^{*} \\
(3.483)\end{aligned}$ \\
\hline Extractive state capacity & & & & & $\begin{array}{r}0.282 \\
(0.211)\end{array}$ \\
\hline Observations & 378 & 351 & 378 & 351 & 284 \\
\hline State fixed effects & yes & yes & yes & yes & yes \\
\hline Year fixed effects & yes & yes & yes & yes & yes \\
\hline $\mathrm{R}^{2}$ & 0.794 & 0.782 & 0.791 & 0.787 & 0.786 \\
\hline Adjusted $\mathrm{R}^{2}$ & 0.769 & 0.755 & 0.766 & 0.758 & 0.742 \\
\hline
\end{tabular}

Notes: Dependent variable is Gini. Huber-White standard errors in parentheses. State and year dummies not included in table.

${ }^{*} p \leq 0.05$.

inequality is likelier to be lower. Nonwhite population has a robust, positive, and statistically significant relationship with inequality. That is, on average states with larger nonwhite populations tend to have lower levels of inequality. Although this result may appear surprising at first glance, some degree of caution should be exercised in interpreting these results. The models are predominantly picking up the over-time, within-state variation, where states with increases in nonwhite populations over time are associated with decreasing levels of inequality. ${ }^{21}$

\section{The Cases of Pará and Rio Grande do Sul}

To further test the theory advanced here and more concretely trace the causal mechanisms, the remainder of the article employs a qualitative paired comparison between the states of Pará and Rio Grande do Sul. A most-different case selection strategy is attractive here as it allows for the effective leverage of Brazil's substantial heterogeneity and requires fewer assumptions for qualitative theory testing (Teune and

\footnotetext{
${ }^{21}$ Changes in nonwhite population over time may be driven by demographic factors, but also because Brazilians have become increasingly more likely to identify as nonwhite (see De Micheli 2018). In models without state fixed effects the relationship flips direction, suggesting that when only cross-sectional variation is analyzed, states with higher nonwhite populations are more likely to possess higher inequality. See the appendix for further details.
} 
Przeworski 1970). Selecting two cases that vary substantially aids in plausibly ruling out myriad factors that may drive social policy making and inequality in both states, while reducing risks associated with most-similar designs where unobserved confounders may lurk in seemingly comparable states. Therefore, I select two states that exhibit extreme variation on virtually every demographic, economic, political, and social dimension except the level of political competition within their respective party systems. ${ }^{22}$ In short, Pará, located in the northern Amazon region, is one of the least economically and socially developed states in Brazil, with an economy highly dependent on the agricultural and mining sectors. Rio Grande do Sul, in contrast, has among the highest economic and social indicators in the country and possesses an economy with strong industrial and manufacturing sectors.

True to generalizations of the north, Pará has a long history of governors and state legislators with strong ties to the military regime propped up by clientelistic and patronage machines with heavy strongholds in the rural regions of the vast state. For much of the 1980s and early 1990s Pará was dominated by the Partido do Movimento Democrático Brasileiro (PMDB) under the administrations of Jader Barbalho and Hélio Gueiros. With such a dominant position in the party system, the PDMB had little incentive to advance social policy and create pluralistic institutions, resulting in a period of limited reform and the subversion of weak political institutions for political gain. Social programs remained largely untouched and agrarian reform was often impeded, while state institutions were kept weak and harnessed as vessels to reward patronage networks and fund electoral machines (Emmi and Marin 1996). ${ }^{23}$

Despite the predominance of traditional politics following redemocratization, beginning in the mid-1990s a wave of political competition from emerging parties produced a competitive rupture, fundamentally altering the political system. The entrance of the PSDB and PT, among other parties, into electoral politics at both the local and state levels in Pará created an upswell of competition against the previously dominant PMDB (Petit 1996; Souza et al. 2011). Indeed, the campaign of Almir Gabriel (PSDB), backed by the Frente Popular Novo Pará coalition, was so fundamentally viewed as a popular front against traditional politics that it even drew the support of presidential candidate Luiz Inácio Lula da Silva. ${ }^{24}$ Although Gabriel would not prove to be successful in his first campaign against Barbalho in 1991, he would go on to defeat the PMDB and former Senate president Jarbas Passarinho in 1994, marking a sharp transition toward robust competition between the PMDB, PSDB, and PT for the next two and a half decades.

With the emergence of a new set of organized parties, O Novo Pará would also usher in an era of party competition centered on programmatic politics and significant social and institutional reform. The Frente Popular Novo Pará (PSDB, PT, PSB, PDT, Partido Comunista do Brasil/PCdoB, and Partido Comunista Brasileiro/PCB) coalition campaigned heavily on education and state reform, particularly through the advance of neoliberal reforms aimed at modernizing the state and reducing inefficiencies, corruption, and patronage. ${ }^{25}$ Making good on their promises, Gabriel and the Novo Pará coalition initiated an array of reforms aiming to decentralize the state, alter the management of state institutions, and reorganize the state apparatus to enhance the implementation of policy and increase efficiency. Dismayed by countless scandals and use of public institutions for political gain, one of the major impetuses behind the neoliberal state reforms was to limit state capture and make "sacrifices to all, and above everything, the definitive break from the practice of waste, clientelism, and complacency with corporate and patrimonial interests, cultures so present that pervade the formation of the Brazilian state and particularly mark Paraense history" (sacrifícios a todos e, acima de tudo, o rompimento definitivo com a prática do desperdício, do clientelismo e da complacência com os interesses corporativistas e patrimonialistas, culturas tão presentes que impregnaram a formação do Estado brasileiro e, particularmente, tão marcantes na história paraense). ${ }^{26}$

\footnotetext{
${ }^{22}$ See the appendix for a more thorough look at the heterogeneity between the two cases.

${ }^{23}$ The use of public resources and state institutions by the PMDB, Barbalho, and Gueiros to advance their own political goals is well documented. Examples include the Escândalo de Aurá, where Barbalho expropriated land for the benefit of business interests who actively funded his political campaigns; the Escândalo Banpará, where Barbalho embezzled millions from the state-owned central bank; and a scandal where it was revealed that a network of appointments to governmental bodies, as well as contracts worth millions of cruzeiros, were awarded to PMDB party members' relatives, including those of Barbalho and Gueiros. See "Barbalho nomeia 9 parentes seus e de amigos no Pará," Jornal do Brasil, April 2, 1986; "No Parú, um festival de nomeações," O Estado de São Paulo, April 2, 1986.

24 "No Pará, uma disputa de ladrões, loucos e traidores," Jornal do Brasil, August 19, 1990.

25 Although the PT was an active coalition member in the 1994 election, it was a largely a union of convenience to defeat the PMDB. The PT would later leave the coalition and become the major competitor to the PSDB in subsequent elections.

${ }^{26}$ Almir Gabriel, "Mensagem à Assembléia Legislativa," 1999, Belém, Pará, 12. Government of the State of Pará, Biblioteca Legislativa Deputado Newton Miranda.
} 
Competition within the Paraense party system also led to significant advances in the realm of social policy. In line with the principles of FUNDEF reforms by the PSDB and Fernando Henrique Cardoso at the federal level, the Novo Pará also dramatically reformed the education sector by emphasizing the role of municipalities in managing public education and initiating the ability for the state government to gauge the quality of education at the local levels (Corrêa 2008). Further reforms were implemented in other domains; the Novo Pará decentralized health care systems and social assistance programs while expanding their networks and increasing public spending and support to municipalities for their effective management. ${ }^{27}$ Changes to social policy were not limited to the Gabriel administration. Rather, social reform became a wedge issue for two competing center-left coalitions to differentiate themselves and attract voters. The intense political competition between the PSDB and PT and their respective coalitions would lead to a series of social reforms expanding on the initial policies of the Novo Pará. For example, the PSDB-backed Simão Jatene expanded on the Gabriel education reforms (Corrêa 2008), while the PT-led coalition and Governor Ana Júlia Carepa emphasized higher education through the expansion of public university matriculation and faculty numbers (Ribeiro et al. 2017).

In contrast to Pará, robust party system competition in Rio Grande do Sul has always been endemic. Some of Brazil's most successful party builders and political parties have deep roots in Rio Grande do Sul, from former president Getúlio Vargas and the Partido Trabalhista Brasileiro (PTB) to Leonel Brizola and the Partido Democrático Trabalhista (PDT). Indeed, the arrival of a competitive party system following redemocratization of the state's elections was nearly instantaneous; in contrast to many other states, Rio Grande do Sul's party system was already highly competitive between three parties (the Partido Democrático Social/PDS, PDT, and PMDB) in the 1982 election, while much of the country's political landscape continued to be dominated by the two-party system manufactured during the military regime. The competitive three-party system would expand with the entrance of the PSDB and PT, guaranteeing a highly pluralistic Assembleia Legislativa and the nonconsecutive alternation of power among the PDT, PMDB, PSDB, and PT, and their respective coalitions, until the present day.

Party system competition was at the root of the construction of more pluralistic political institutions and participatory budgeting in Rio Grande do Sul. Amid political competition from the PT at the local levels, the PDT and PMDB implemented participatory budgetary and pluralistic state institutions-most prominently, the coredes and consulta populares-to promote the partisan goals of their creators, and more importantly, safeguard their future access to decision-making in the face of electoral losses (Goldfrank and Schneider 2006, 8-15). The movement toward pluralistic institution building was not exclusive to the PDT and PMDB, however, as the Frente Popular coalition (PT, PCdoB, PSB, PCB) under Governor Olívio Dutra also implemented a number of reforms aimed at democratizing budgetary and administrative processes at the state level (Faria 2006). In other words, closely contested elections between multiple parties in Rio Grande do Sul created an incentive structure for parties to construct state reforms and institutions that would secure future access, reduce the ability for incumbents or rivals to engage in state capture and patronage, as well as enable broader segments of the population to participate in decision-making and budgetary processes. Although far from the only factor contributing to Rio Grande do Sul's high socioeconomic development indicators, the state's long history of participatory institutions have been directly linked to increases in redistribution, largely because of greater access to decision-making from lower classes as well as more progressive and higher social spending (Marquetti 2003; Goldfrank and Schneider 2006; Touchton and Wampler 2014).

Party system competition also led to the democratization of social programs and implementation of social policy, particularly in the realm of education reform. The return of democratic politics brought tightly contested elections between the centrist PDS, PMDB, and PSDB coalitions, and the PT and PDT-led coalitions on the left, and these parties heavily engaged in policy competition on education reform to attract voters. The PDS and Governor Jair Soares made education a focal point of their social policy agenda, pursuing a number of proposals to expand the access and funding of primary and secondary schooling. ${ }^{28}$ Under pressure from teacher unions, Soares also initiated the popular election of school directors, a move that would kick-start a decades-long string of reforms across multiple administrations aimed at increasing access to management of the education system and curriculum (Amaral 2008, 252-253). Indeed, the democratization of education became a central issue in subsequent elections as multiple parties and coalitions attempted

\footnotetext{
${ }^{27}$ Almir Gabriel,. "Mensagem à Assembléia Legislativa," 2000, Belém, Pará, 77-85. Government of the State of Pará, Biblioteca Legislativa Deputado Newton Miranda.

${ }^{28}$ See Jair Soares, "Programa de Governo, 1983-1987," Porto Alegre, Rio Grande do Sul, 133-144. Government of the State of Rio Grande do Sul, Biblioteca Borges de Medeiros.
} 
to take ownership of the approach. Education reform was a major pillar of the PDT in 1990, with the Frente Progressista Gaúcha (PDT, PSDB, PCdoB) under Governor Alceu Collares implementing Centros Integrados de Educação Pública at multiple levels of instruction, an educational system popularized by Leonel Brizola in Rio de Janeiro centered on full-time study and supplying underprivileged students with basic needs (Silva 2015, 886-887). On the back of their first state-level electoral victory, the PT and its Frente Popular Gaúcha coalition (PT, PCdoB, PSB, and PCB) further pushed for the democratization of education programs, implementing the Constituinte Escolar designed to expand on the elections of education administrators as well as increase the autonomy of pedagogical practices (Camini 2002).

Although isolating the direct effects of these social and institutional reforms on inequality is outside the scope of this article, these case studies have shown that, even in diametrically opposed socioeconomic environments, party system competition has been integral to the advance of broad social policy and pluralistic institution building. In Pará, a competitive rupture coincided with a sharp shift from traditional clientelistic politics toward more programmatic policy making, while an environment of robust party system competition in Rio Grande do Sul has promoted the persistent and deep implementation of education reforms and participatory state institutions.

\section{Conclusion}

This article has argued that struggles for redemocratization contributed to the formation and spread of comparatively more organized political parties, and their entrance into traditional party systems spurred uneven modes of party system competition and differing patterns of policy and socioeconomic outcomes. Where traditional political strongholds have remained entrenched and subnational party systems less competitive, social reform has been limited and inequality more likely to persist. In contrast, in states where competitive ruptures have enhanced competition within subnational party systems, the advance of social policy has been more common, placing downward pressures on income inequality.

One may contend that it is possible that the relationship between party system competition and inequality is operating in the opposite causal direction, that is, inequality may be shaping dynamics of competition across party systems. Indeed, classic literature stressed that large economic differences between social groupsparticularly between the rich and poor-can potentially increase political conflict (Lipset 1959), and equity may contribute to more robust political competition while unequal conditions are likely to undermine the growth (or allowance) of political parties with bases in the popular sectors (Dahl 1971). Yet the sequencing of political competition and changes in inequality in subnational Brazil suggests that the causal direction is operating in the manner advanced here. First, the formation of parties such as the PSDB and PT stemmed at a point in time at which income inequality in Brazil was at its approximate peak. Furthermore, environments of political competition have steadily become more robust (albeit at uneven levels across states) in the first two decades of democratic rule, long before any significant waves of income redistribution occurred in the late 1990s and 2000s (Borges 2007). Lastly, as the case of Pará makes clear, robust party system competition can emerge in environments of high inequality. Therefore, both theoretically and empirically, I argue that party system competition is driving broader patterns of socioeconomic outcomes, not the other way around.

Although recent research suggests that federalized states face unique obstacles to centralized redistribution (Beramendi, Rogers, and Díaz-Cayeros 2017), the theory is well equipped to travel to other federal systems: for example, Argentina, Canada, India, Mexico, Nigeria, the United States, and Venezuela. While it may not exhibit the same degree of external validity in unitary states, especially in those where subnational political or administrative units do not exercise significant leverage to design and implement their own social policy, it is certainly plausible that robust political competition may produce improved governance or socioeconomic outcomes at the local level. Indeed, existing research has found that party competition at the local level increases government efficiency and public service performance in differing political and social contexts (e.g., Ashworth et al. 2014; and Sørensen 2014).

Inequality is not intractable in one of the world's most unequal countries. Contrary to literature that stresses the importance of democracy for initiating redistribution, mere democratization may not provide the necessary conditions for the amelioration of inequality. It is critical to understand how party systems shape democratic competition and potentially condition redistribution within democracies. Granted, substantial alleviation of inequality often requires a minimal degree of favorable economic conditions. How the current tumultuous and potentially destabilizing economic and political trends in contemporary Brazil influence the relationship between party systems and inequality at the subnational level remains to be seen. Just as democratization can induce competitive ruptures and spur greater party system development at the subnational level, it is just as possible that other forms of pervasive democratic contention can lead to the atomization of party systems and increases in inequality as well. 


\section{Additional File}

The additional file for this article can be found as follows:

- Online appendix. Appendix. DOI: https://doi.org/10.25222/larr.1062.s1

\section{Acknowledgements}

I thank Michael Albertus, Sarah Berens, Wendy Hunter, David De Micheli, Tom Pepinsky, three anonymous reviewers, and a number of participants at the Cornell Comparative Politics Workshop for helpful comments and suggestions on previous drafts. Special thanks to André Borges, Sari Niedzwiecki, and Pedro Floriano Ribeiro for sharing data, and to the Center for the Study of Inequality and Mario Einaudi Center at Cornell for helping fund this project.

\section{Author Information}

Vincent Mauro is a PhD candidate in the Department of Government at Cornell University. He studies comparative politics and the politics of inequality. His book project "Party Systems and Democratic Redistribution" investigates how party systems shape paths of social reform, redistribution, and economic inequality in Latin America and beyond.

\section{References}

Abers, Rebecca Neaera. 2000. Inventing Local Democracy: Grassroots Politics in Brazil. Boulder, CO: Lynne Rienner.

Abramowitz, Alan I. 1991. "Incumbency, Campaign Spending, and the Decline of Competition in US House Elections." Journal of Politics 53 (1): 34-56. DOI: https://doi.org/10.2307/2131719

Abrucio, Fernando Luiz. 1998. Os barões da federação: Os governadores e a redemocratização brasileira. São Paulo: Editora Hucitec.

Alves, Jorge Antonio. 2015. "(Un?)Healthy Politics: The Political Determinants of Subnational Health Systems in Brazil." Latin American Politics and Society 57 (4): 119-142. DOI: https://doi.org/10.1111/ j.1548-2456.2015.00292.x

Alves, Jorge Antonio, and Wendy Hunter. 2017. "From Right to Left in Brazil's Northeast: Transformation, or "Politics as Usual'?" Comparative Politics 49 (4): 437-455. DOI: https:// doi.org/10.5129/001041517821273062

Amaral, Josiane Carolina Soares Ramos do. 2008. "A gestão democrática da educação na rede estadual de ensino do Rio Grande do Sul (1985-2001)." Revista Brasileira de Política e Administração da Educação 24 (2): 249-271.

Arvate, Paulo Roberto. 2013. "Electoral Competition and Local Government Responsiveness in Brazil." World Development 43 (1): 67-83. DOI: https://doi.org/10.1016/j.worlddev.2012.11.004

Ashworth, John, Benny Geys, Bruno Heyndels, and Fanny Wille. 2014. "Competition in the Political Arena and Local Government Performance." Applied Economics 46 (19): 2246-2276. DOI: https://doi.org/10.1 080/00036846.2014.899679

Baiocchi, Gianpaolo. 2005. Militants and Citizens: The Politics of Participatory Democracy in Porto Alegre. Stanford, CA: Stanford University Press.

Barros, Ricardo, Mirela de Carvalho, Samuel Franco, and Rosane Mendonça. 2010. "Markets, the State, and the Dynamics of Inequality in Brazil." In Declining Inequality in Latin America: A Decade of Progress?, edited by Luis Felipe López-Calva and Nora Claudia Lustig, 134-174. Washington, DC: Brookings Institution Press.

Beramendi, Pablo, Melissa Rogers, and Alberto Díaz-Cayeros. 2017. "Barriers to Egalitarianism: Distributive Tensions in Latin American Federations." Latin American Research Review 52 (4): 529-551. DOI: https:// doi.org/10.25222/larr.31

Besarria, Cássio Nobrega, Jevuks Matheus Araujo, Andréa Ferreira Da Silva, Erika Fernanda Miranda Sobral, and Thiago Geovane Pereira. 2018. "Effects of Income Inequality on the Economic Growth of Brazilian States: An Analysis Using the Cointegrated Panel Model." International Journal of Social Economics 45 (3): 548-563. DOI: https://doi.org/10.1108/IJSE-02-2017-0039

Borges, André. 2007. "Rethinking State Politics: The Withering of State Dominant Machines in Brazil." Brazilian Political Science Review 1 (2): 108-156. DOI: https://doi.org/10.1590/S1981-3821200700020 0004

Borges, André. 2008. "State Government, Political Competition and Education Reform: Comparative Lessons from Brazil." Bulletin of Latin American Research 27 (2): 235-254. DOI: https://doi.org/10.1111/j.14709856.2008.00265.x 
Borges, André. 2011. "The Political Consequences of Center-Led Redistribution in Brazilian Federalism: The Fall of the Subnational Party Machines." Latin American Research Review 46 (3): 21-45. DOI: https:// doi.org/10.1353/lar.2011.0047

Brollo, Fernanda, and Tommaso Nannicini. 2012. "Tying Your Enemy's Hands in Close Races: The Politics of Federal Transfers in Brazil." American Political Science Review 106 (4): 742-761. DOI: https:// doi.org/10.1017/S0003055412000433

Calvo, Ernesto, and Lorena Moscovich. 2017. "Inequality, Protests, and the Progressive Allocation of Cash Transfers in the Argentine Provinces." Latin American Politics and Society 59 (2): 3-26. DOI: https:// doi.org/10.1111/laps.12016

Camini, Lúcia. 2002. "A experiência de política de educação pública." In Tempo de desafios: a política social democrática e popular no governo do Rio Grande do Sul, edited by Laura Tavares Soares, 29-45. São Paulo: Vozes.

Cleary, Matthew R. 2007. "Electoral Competition, Participation, and Government Responsiveness in Mexico." American Journal of Political Science 51 (2): 283-299. DOI: https://doi.org/10.1111/j.15405907.2007.00251.x

Corrêa, Paulo Ségio de Almeida. 2008. "A reforma do Estado nos anos 90 e suas implicações para as políticas públicas educacionais na região amazônica." Novos Cadernos NAEA 3 (2): 3-29. DOI: https:// doi.org/10.5801/ncn.v3i2.27

Costa, Francisco, Jason Garred, João Paulo Pessoa. 2016. "Winners and Losers from a Commodities-for-Manufactures Trade Boom." Journal of International Economics 102 (1): 50-69. DOI: https://doi.org/10.1016/j.jinteco.2016.04.005

Dahl, Robert A. 1971. Polyarchy: Participation and Opposition. New Haven, CT: Yale University Press.

De Micheli, David. 2018. "The Racialized Effects of Social Programs in Brazil." Latin American Politics and Society 60 (1): 52-75. DOI: https://doi.org/10.1017/lap.2017.6

Desposato, Scott. 2001. "Institutional Theories, Societal Realities, and Party Politics in Brazil." PhD dissertation, University of California, Los Angeles.

Díaz-Cayeros, Alberto. 2008. "Electoral Risk and Redistributive Politics in Mexico and the United States." Studies in Comparative International Development 43 (2): 129-150. DOI: https://doi.org/10.1007/ s12116-008-9020-1

Donaghy, Maureen M. 2011. "Do Participatory Governance Institutions Matter? Municipal Councils and Social Housing Programs in Brazil." Comparative Politics 44 (1): 83-102. DOI: https://doi.org/10.5129/ $001041510 X 13815229366606$

Eifert, Benn, Edward Miguel, and Daniel N. Posner. 2010. "Political Competition and Ethnic Identification in Africa." American Journal of Political Science 54 (2): 494-510. DOI: https://doi.org/10.1111/j.15405907.2010.00443.x

Emmi, Marília Ferreira, and Rosa Elizabeth Acevedo Marin. 1996. "Crise e rearticulação das oligarquias no Pará." Revista do Instituto de Estudos Brasileiros 40 (1): 51-68. DOI: https://doi.org/10.11606/issn.2316901X.v0i40p51-68

Ewig, Christina. 2016. "Reform and Electoral Competition: Convergence toward Equity in Latin American Health Sectors." Comparative Political Studies 49 (2): 184-218. DOI: https:// doi.org/10.1177/0010414015600467

Fairfield, Tasha, and Candelaria Garay. 2017. "Redistribution under the Right in Latin America: Electoral Competition and Organized Actors in Policymaking." Comparative Political Studies 50 (14): 1871-1906. DOI: https://doi.org/10.1177/0010414017695331

Faria, Cláudia Feres. 2006. "Fóruns participativos, controle democrático e a qualidade da democracia no Rio Grande do Sul: A experiência do governo Olívio Dutra (1999-2002)." Opinião Pública 12 (12): 378-406. DOI: https://doi.org/10.1590/S0104-62762006000200007

Garay, Candelaria. 2016. Social Policy Expansion in Latin America. New York: Cambridge University Press. DOI: https://doi.org/10.1017/9781316585405

Gervasoni, Carlos. 2018. Hybrid Regimes within Democracies: Fiscal Federalism and Subnational Rentier States. New York: Cambridge University Press. DOI: https://doi.org/10.1017/9781108590679

Gibson, Edward L. 2013. Boundary Control: Subnational Authoritarianism in Federal Democracies. New York: Cambridge University Press. DOI: https://doi.org/10.1017/CBO9781139017992

Gibson, Edward L., and Julieta Suarez-Cao. 2010. "Federalized Party Systems and Subnational Party Competition: Theory and an Empirical Application to Argentina." Comparative Politics 43 (1): 21-39. DOI: https://doi.org/10.5129/001041510X12911363510312 
Giraudy, Agustina. 2015. Democrats and Autocrats: Pathways of Subnational Undemocratic Regime Continuity within Democratic Countries. New York: Cambridge University Press. DOI: https://doi.org/10.1093/acpr of:oso/9780198706861.001.0001

Goldfrank, Benjamin, and Aaron Schneider. 2006. "Competitive Institution Building: The PT and Participatory Budgeting in Rio Grande do Sul." Latin American Politics and Society 48 (3): 1-31. DOI: https://doi.org/10.1111/j.1548-2456.2006.tb00354.x

González, Lucas. 2017. "Electoral Competition and Social Spending in the Argentine Provinces." Journal of Politics in Latin America 9 (1): 91-124. DOI: https://doi.org/10.1177/1866802X1700900104

González, Lucas I., and Ignacio Mamone. 2015. "Distributive Politics in Developing Federal Democracies: Compensating Governors for Their Territorial Support." Latin American Politics and Society 57 (3): 50-76. DOI: https://doi.org/10.1111/j.1548-2456.2015.00279.x

Gouvêa, Raphael, and Daniele Girardi. 2019. "Partisanship and Local Fiscal Policy: Evidence from Brazilian Cities." UMass Amherst Economics Working Papers, 2019-06.

Hagopian, Frances. 1996. Traditional Politics and Regime Change in Brazil. New York: Cambridge University Press. DOI: https://doi.org/10.1017/CBO9780511584862

Harbers, Imke. 2015. "Taxation and the Unequal Reach of the State: Mapping State Capacity in Ecuador." Governance 28 (3): 373-391. DOI: https://doi.org/10.1111/gove.12117

Hecock, R. Douglas. 2006. "Electoral Competition, Globalization, and Subnational Education Spending in Mexico, 1999-2004." American Journal of Political Science 50 (4):950-961. DOI: https://doi.org/10.1111/ j.1540-5907.2006.00226.x

Holbrook, Thomas M., and Emily Van Dunk. 1993. "Electoral Competition in the American States." American Political Science Review 87 (4): 955-962. DOI: https://doi.org/10.2307/2938827

Huber, Evelyne, and John D. Stephens. 2012. Democracy and the Left: Social Policy and Inequality in Latin America. Chicago: University of Chicago Press. DOI: https://doi.org/10.7208/ chicago/9780226356556.001.0001

Hunter, Wendy, and Timothy Power. 2007. "Rewarding Lula: Executive Power, Social Policy, and the Brazilian Elections of 2006." Latin American Politics and Society 49 (1): 1-30. DOI: https:// doi.org/10.1111/j.1548-2456.2007.tb00372.x

Kale, Sunila S., and Nimah Mazaheri. 2019. "Indigenous Welfare, Tribal Homelands, and the Impact of Civil Society Organizations." In Inside Countries: Subnational Research in Comparative Politics, edited by Agustina Giraudy, Eduardo Moncada, and Richard Snyder, 287-317. New York: Cambridge University Press. DOI: https://doi.org/10.1017/9781108678384.009

Kellerman, Michael. 2007. "Power Resources Theory and Inequality in the Canadian Provinces." Unpublished paper, Harvard University.

Kelly, Nathan J., and Christopher Witko. 2012. "Federalism and American Inequality." Journal of Politics 74 (2): 414-426. DOI: https://doi.org/10.1017/S0022381611001678

Key, V. O. 1949. Southern Politics in State and Nation. New York: Vintage Books.

Kitschelt, Herbert, and Steven I. Wilkinson, eds. 2007. Patrons, Clients and Policies: Patterns of Democratic Accountability and Political Competition. New York: Cambridge University Press. DOI: https:// doi.org/10.1017/CBO9780511585869

Levitsky, Steven, James Loxton, and Brandon Van Dyck. 2016. "Introduction: Challenges of Party-Building in Latin America." In Challenges of Party-Building in Latin America, edited by Steven Levitsky, James Loxton, Brandon Van Dyck, and Jorge I. Domínguez, 1-48. New York: Cambridge University Press. DOI: https:// doi.org/10.1017/CBO9781316550564.001

Lipset, Seymour Martin. 1959. "Some Social Requisites of Democracy: Economic Development and Political Legitimacy." American Political Science Review 53 (1): 69-105. DOI: https://doi.org/10.2307/1951731

Lipset, Seymour Martin, and Stein Rokkan, eds. 1967. Party Systems and Voter Alignments: Cross-national Perspectives. New York: Free Press.

Lustig, Nora. 2017. "Fiscal Redistribution and Ethnoracial Inequality in Bolivia, Brazil, and Guatemala." Latin American Research Review 52 (2): 208-220. DOI: https://doi.org/10.25222/larr.90

Marquetti, Adalmir. 2003. "Participação e redistribuição: o orçamento participativo em Porto Alegre." In A inovação democrática no Brasil: $O$ orçamento participativo, edited by Leonardo Avritzer and Zander Navarro, 129-156. São Paulo: Cortez Editora.

Montero, Alfred P. 2012. "A Reversal of Political Fortune: The Transitional Dynamics of Conservative Rule in the Brazilian Northeast." Latin American Politics and Society 54 (1): 1-36. DOI: https://doi.org/10.1111/ j.1548-2456.2012.00141.x 
Montero, Alfred P. 2014. Brazil: Reversal of Fortune. Hoboken, NJ: John Wiley and Sons.

Morgan, Jana, and Nathan J. Kelly. 2017. "Social Patterns of Inequality, Partisan Competition, and Latin American Support for Redistribution." Journal of Politics 79 (1): 193-209. DOI: https:// doi.org/10.1086/687412

Niedzwiecki, Sara. 2016. "Social Policies, Attribution of Responsibility, and Political Alignments." Comparative Political Studies 49 (4): 457-498. DOI: https://doi.org/10.1177/0010414015612392

Niedzwiecki, Sara. 2018. Uneven Social Policies: The Politics of Subnational Variation in Latin America. New York: Cambridge University Press. DOI: https://doi.org/10.1017/9781108588225

Petit, Pere. 1996. A esperança equilibrista: A trajetória do PT no Pará. São Paulo: Boitempo.

Pribble, Jennifer. 2010. "Worlds Apart: Social Policy Regimes in Latin America." Studies in Comparative International Development 46 (1): 191-216. DOI: https://doi.org/10.1007/s12116-010-9076-6

Pribble, Jennifer. 2013. Welfare and Party Politics in Latin America. New York: Cambridge University Press. DOI: https://doi.org/10.1017/CBO9781139343299

Ribeiro, Giselle dos Santos, Tayanne de Fátima Almeida Tabosa dos Reis, Valeria Silva de Moraes Novais, Ana Paula Batista da Silva Brito, and Emerson Duarte Monte. 2017. "O financiamento das IEEs brasileiras frente ao processo de expansão da educação superior: Um estudo da Universidade do Estado do Pará (2003-2010)." Revista de Financiamento da Educação 7 (9): 1-15. DOI: https://doi.org/10.17648/ fineduca-2236-5907-v7-70057

Ribeiro, Pedro Floriano. 2010. Dos sindicatos ao governo: A organização nacional do PT de 1980 a 2005. São Paulo: Editora da Universidade Federal de São Carlos; FAPESP.

Samuels, David. 2003. Ambition, Federalism, and Legislative Politics in Brazil. New York: Cambridge University Press. DOI: https://doi.org/10.1017/CBO9780511510366

Samuels, David, and Fernando Luiz Abrucio. 2000. "Federalism and Democratic Transitions: The 'New' Politics of the Governors of Brazil." Publius: The Journal of Federalism 30 (2): 43-62. DOI: https:// doi.org/10.1093/oxfordjournals.pubjof.a030084

Samuels, David, and Cesar Zucco. 2014. "Crafting Mass Partisanship at the Grass Roots." British Journal of Political Science 45 (1): 755-775. DOI: https://doi.org/10.1017/S0007123413000549

Santos, Fabiano Guilherme Mendes. 2001. O poder legislativo nos estados: Diversidade e convergência. Rio de Janeiro: Editora FGV.

Schneider, Aaron. 2001. "Federalism against Markets: Local Struggles for Power and National Fiscal Adjustment in Brazil." PhD dissertation, University of California, Berkeley.

Schneider, Aaron. 2006. "Responding to Fiscal Stress: Fiscal Institutions and Fiscal Adjustment in Four Brazilian States." Journal of Development Studies 42 (3): 402-425. DOI: https:// doi.org/10.1080/00220380600576169

Silva, Roberto Rafael Dias da. 2015. "Políticas de ampliação da jornada escolar para o Ensino Médio no Rio Grande do Sul: Um estudo sobre o conhecimento escolar." Ensaio: Avaliação e Políticas Públicas em Educação 23 (89): 869-900. DOI: https://doi.org/10.1590/S0104-40362015000400004

Soares, Márcia Miranda, and Pedro Robson Pereira Neiva. 2011. "Federalism and Public Resources in Brazil: Federal Discretionary Transfers to States." Brazilian Political Science Review 5 (2): 94-116.

Sørensen, Rune J. 2014. "Political Competition, Party Polarization, and Government Performance." Public Choice 161 (3-4): 427-450. DOI: https://doi.org/10.1007/s11127-014-0168-0

Souza, Carlos Augusto, Dolores Silva, Edir Siqueira, and Pedro Santos Mundim. 2011. "Da avaliação negativa à vitória nas urnas: Voto e estratégias de campanha para prefeito de Belém." In Como o eleitor escolhe seu prefeito: Campanha e voto nas eleições municipais, edited by Antonio Lavaeda and Helcimara Telles, 255-280. Rio de Janeiro: Editora FGV.

Teune, Henry, and Adam Przeworski. 1970. The Logic of Comparative Social Inquiry. New York: WileyInterscience.

Touchton, Michael, Natasha Borges Sugiyama, and Brian Wampler. 2017. "Democracy at Work: Moving Beyond Elections to Improve Well-Being." American Political Science Review 111 (1): 68-92. DOI: https:// doi.org/10.1017/S000305541600068X

Touchton, Michael, and Brian Wampler. 2014. "Improving Social Well-Being through New Democratic Institutions." Comparative Political Studies 47 (10): 1442-1469. DOI: https://doi.org/10.1177/00104140 13512601

Van Cott, Donna Lee. 2000. "Party System Development and Indigenous Populations in Latin America: The Bolivian Case." Party Politics 6 (2): 155-174. DOI: https://doi.org/10.1177/135406880000600 2002 
Van Dyck, Brandon, and Alfred P. Montero. 2015. "Eroding the Clientelist Monopoly: The Subnational Left Turn and Conservative Rule in Northeastern Brazil." Latin American Research Review 50 (4): 116-138. DOI: https://doi.org/10.1353/lar.2015.0055

Wampler, Brian. 2010. Participatory Budgeting in Brazil: Contestation, Cooperation, and Accountability. University Park: Pennsylvania State University Press.

Wooldridge, Jeffrey M. 2010. Econometric Analysis of Cross Section and Panel Data. Cambridge, MA: MIT Press. Zucco, Cesar, Jr. 2013. "When Payoffs Pay Off: Conditional Cash Transfers and Voting Behavior in Brazil 2002-10." American Journal of Political Science 57 (4): 810-822. DOI: https://doi.org/10.2139/ ssrn. 1753234

How to cite this article: Mauro, Vincent. 2021. Party Systems, Political Competition, and Inequality in Subnational Brazil. Latin American Research Review 56(4), pp. 797-813. DOI: https://doi.org/10.25222/larr.1062

Copyright: (c) 2021 The Author(s). This is an open-access article distributed under the terms of the Creative Commons Attribution 4.0 International License (CC-BY 4.0), which permits unrestricted use, distribution, and reproduction in any medium, provided the original author and source are credited. See http://creativecommons.org/ licenses/by/4.0/. 